\title{
Risks of Perfluoroalkyl and Polyfluoroalkyl Substances (PFAS) for Sustainable Water Recycling via Aquifers
}

\author{
Declan Page ${ }^{1, * \mathbb{D}}$, Joanne Vanderzalm ${ }^{1}$, Anupama Kumar ${ }^{1}$, Ka Yu Cheng ${ }^{2,3}$, \\ Anna H. Kaksonen ${ }^{2,4}$ and Stuart Simpson ${ }^{5}$ \\ 1 CSIRO Land and Water, Locked Bag 2, Glen Osmond, SA 5064, Australia \\ CSIRO Land and Water, Private Bag No. 5, Wembley, WA 6913, Australia \\ 3 School of Engineering and Information Technology, Murdoch University, Murdoch, WA 6150, Australia \\ 4 School of Biomedical Sciences, University of Western Australia, 35 Stirling Highway, Crawley, WA 6009, \\ Australia \\ 5 Centre for Environmental Contaminants Research, CSIRO Land and Water, Locked Bag 2007, Kirrawee, \\ NSW 2232, Australia \\ * Correspondence: declan.page@csiro.au; Tel.: +61-8-8303-8748
}

Received: 3 July 2019; Accepted: 15 August 2019; Published: 20 August 2019

\begin{abstract}
The prediction of the fate of perfluoroalkyl and polyfluoroalkyl substances (PFAS) in water recycling with urban stormwater and treated wastewater is important since PFAS are widely used, persistent, and have potential impacts on human health and the environment. These alternative water sources have been utilized for water recycling via aquifers or managed aquifer recharge (MAR). However, the fate of these chemicals in MAR schemes and the potential impact in terms of regulation have not been studied. PFAS can potentially be transported long distances in the subsurface during MAR. This article reviews the potential risks to MAR systems using recycled water and urban stormwater. To date, there are insufficient data to determine if PFAS can be degraded by natural processes or retained in the aquifer and become suitable pre-treatment or post-treatment technologies that will need to be employed depending upon the end use of the recovered water. The use of engineered pre-treatment or post-treatment methods needs to be based on a 'fit for purpose' principle and carefully integrated with the proposed water end use to ensure that human and environmental health risks are appropriately managed.
\end{abstract}

Keywords: perfluoroalkyl and polyfluoroalkyl substances (PFAS); treatment; urban water; water recycling; managed aquifer recharge (MAR)

\section{Introduction}

Perfluoroalkyl and polyfluoroalkyl substances (PFAS) are a group of both emerging and persistent organic pollutants that have been used extensively by the industry as well as in consumer products for more than 30 years [1-4]. Because of their carbon-fluorine chain, PFAS are inert, show resistance to high temperatures, and repel both oil and water [5,6]. They have been produced for both industrial and commercial applications including aqueous fire-fighting foam, lubricants, stain and water-repelling treatments on paper, and textiles including fabric and carpet [7]. Due to their widespread use, they are now widely distributed in the environment [8], and typically at higher concentrations near fire training/fire response sites, industrial sites, landfills, and wastewater treatment plants/biosolids [9].

PFAS have recently received international attention due to their persistence and toxicity and their ubiquitous presence in the environment $[7,10]$. PFAS such as perfluorooctane sulfonate (PFOS) and perfluorooctanoic acid (PFOA) have been found in fish, birds, mammals [8,11-13], and human blood at 
concentrations of several to tens of milligrams per liter [14]. PFAS in blood serum can disrupt human hormone activity [15] and their developmental toxicity to mammals has been reported [3]. PFOS, its salts, and perfluorooctane sulfonyl fluoride (PFOSF) were listed under the Stockholm Convention on Persistent Organic Pollutants for restriction in 2009 [16]. Although PFAS was not regulated during most of the last 50 to 60 years, various international authorities in recent years have established a number of health-based regulatory values and evaluation criteria [17-19]. For example, data reported under the USEPA's unregulated contaminants monitoring rule program found that approximately six million residents of the United States have drinking water with PFOA or PFOS concentrations, or both, above the USEPA's lifetime health advisory (HA) of $0.07 \mu \mathrm{g} / \mathrm{L}$ [20]. However, there remain considerable uncertainties in predicting the long-term risks PFAS pose humans [21] and ecosystems, where chronic effect data are lacking for many environments and classes of organisms [10,22,23].

PFAS remain challenging to treat because of the strong carbon-fluorine bonds by conventional water treatment methods. PFAS are not easily degraded by physical or chemical mechanisms once in the environment [24]. With the relatively high solubility, variable adsorption potentials [10,25], and very low or possibly negligible volatility [7], they are also not readily removed by conventional engineered water-treatment technologies [26].

The elevated concentrations of PFAS in the environment potentially impact the water recycling schemes that harvest urban stormwater runoff and or utilize treated wastewater. This is also the case where these alternative water sources may be introduced to groundwater systems via managed aquifer recharge (MAR) as well as aquifer treatment and disposal schemes. The concentrations of PFAS in these sources of aquifer recharge and their subsequent fate in the subsurface have not been considered to date and could potentially impact on urban aquifer infiltration and water recycling schemes.

This study draws on recent scientific knowledge of aquifer processes to assess the potential risks of PFAS to urban aquifer infiltration and water recycling schemes. In particular, it seeks to characterize the sources and concentrations of PFAS in urban waters [1], discuss PFAS fate and processes affecting the potential for aquifers to treat PFAS including the effects of geology, microbiology, and MAR configurations [2], determine potential configurations of hybrid MAR/engineered pre-treatment and post-treatment options [3], and explore the implications of regulation that governs aquifer infiltration schemes [4]. Various types of urban MAR schemes and sources of water for reuse via MAR are introduced, the potential water quality implications of PFAS are discussed, and the opportunities that MAR may provide as well as challenges are outlined.

\section{Role of MAR in Urban Water Management}

MAR is the purposeful recharge of water to aquifers for reuse and/or environmental benefit [27]. A conceptual example of an Aquifer Storage and Recovery injection scheme and a Soil Aquifer Treatment infiltration MAR scheme is given in Figure 1.

MAR requires the management of both water quantity and quality to ensure protection of public health and the environment while developing a water resource for beneficial use. Enhancing natural rates of groundwater recharge via MAR provides an important potential source of water for urban areas where impervious cover has altered the natural recharge regime.

MAR can be used to store water from various sources, including urban stormwater, treated wastewater, desalinated seawater, rivers, lakes, and rainwater [28]. With appropriate pre-treatment before recharge and sometimes post-treatment on recovery of the water, the water recovered from the aquifer may be used for drinking water supplies, industrial water, irrigation, toilet flushing, and sustaining ecosystems [28]. This study focuses on urban stormwater and treated wastewater as source water for MAR. 

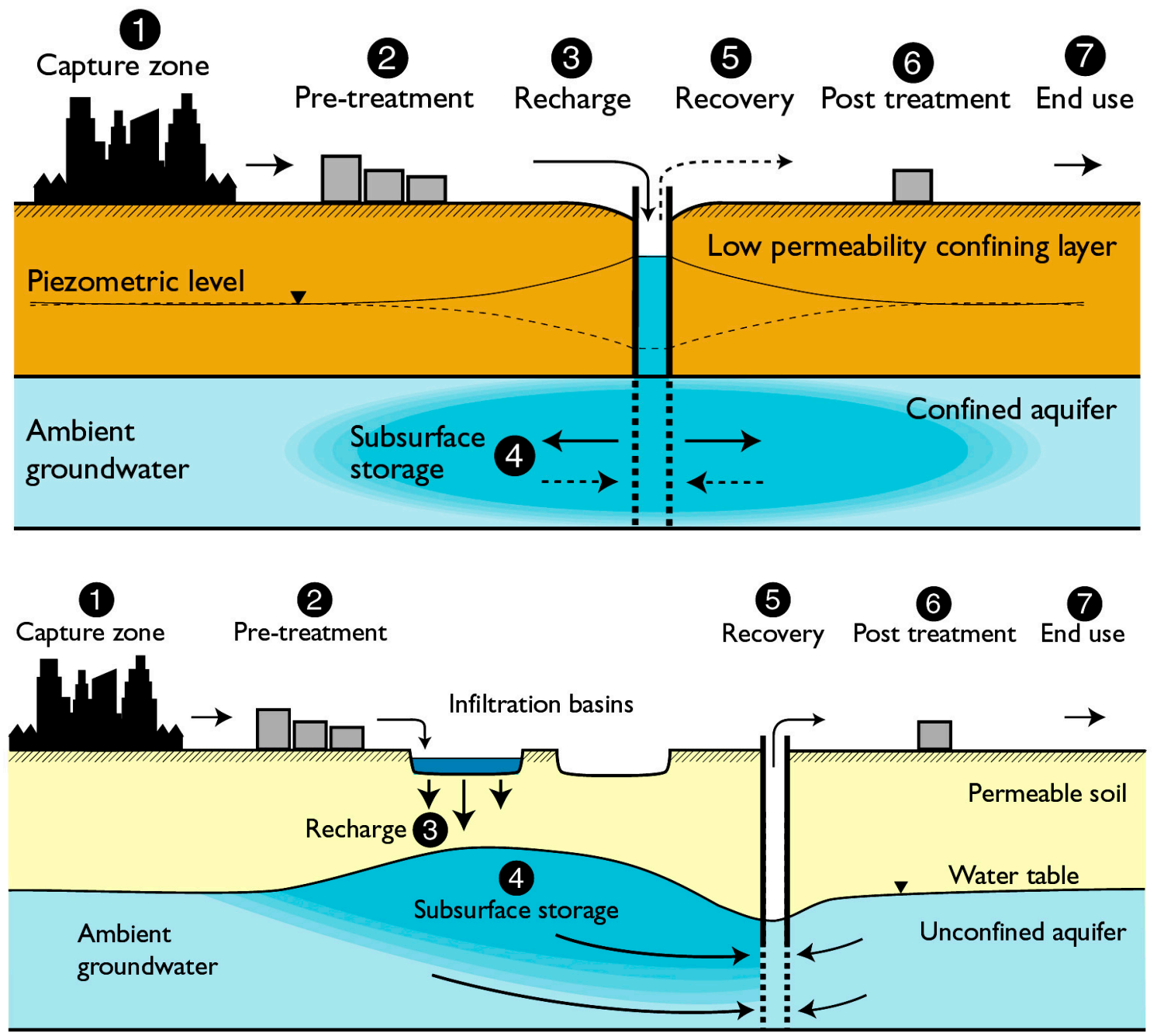

Figure 1. MAR injection and infiltration schemes. Top: Aquifer Storage and Recovery. Bottom: Soil Aquifer Treatment (after [28]).

While there are many configurations of MAR schemes (e.g., as described by Page and coworkers [28], water is generally recovered via an extraction well, as shown for both infiltration schemes and also direct injection methods (Figure 1). However, this is not always the case. For some configurations of MAR, the recharged water remains in the environment such as where water is recharged for ecosystem support or for saltwater intrusion barriers. This is also typical for aquifer treatment and disposal schemes. It is for these examples where pre-treatment of the recharge water is particularly important for the protection of the environment. Aquifers can also be used to treat and dispose treated wastewater. This can help reduce the concentration of some contaminants before the water reaches surface water bodies such as rivers, lakes, and the sea. Figure 1 has been divvied into seven components of a MAR scheme, where water quality interventions commonly occur. The following sections utilize the seven components of a MAR scheme in Figure 1 to discuss the PFAS-related challenges and gaps for further research.

\section{PFAS in the Capture Zone and Urban Source Waters Used for MAR}

\subsection{PFAS in Urban Stormwater}

The primary limitation to stormwater harvesting and reuse in urban areas is the ability to store the water from potentially seasonal runoff events for subsequent use when water is in demand, typically 
during the dry season. MAR can provide an economical method of storing and treating stormwater in urban areas.

Urban stormwater runoff used as a source water for MAR carries various contaminants from the urban catchment, such as heavy metals, nutrients, turbidity, pathogens, and micropollutants such as herbicides [29]. While stormwater management practices can remove many of these contaminants [15], conventional approaches such as water sensitive urban design and constructed wetlands may not efficiently remove micropollutants including PFAS from stormwater.

PFAS in urban water bodies mainly come from urban stormwater and wastewater treatment plants [30]. However, Zushi and coworkers [31] reported that an urban river received a higher load of PFAS from stormwater runoff than from wastewater treatment plants. Furthermore, different PFAS profiles between wastewater treatment plant effluents and urban stormwater were found in Japan [32]. Urban stormwater was found to contain more long-chain ( $>8$ perfluorinated carbons) and even-chain perfluorocarboxylates than wastewater treatment plant effluents [32,33].

PFAS has been detected in 100\% of urban stormwater samples in the US from seven storm events [34]. Monitoring results showed that PFAS in urban stormwater from residential areas mainly came from rainfall. Conversely, non-atmospheric sources at both industrial and commercial areas contributed PFAS in stormwater runoff. Concentrations of PFAS in stormwater runoff differ from event to event with the total concentration of PFAS ranging from 14.3 to $96.0 \mathrm{ng} / \mathrm{L}$ [34]. The most abundant PFAS in stormwater runoff were PFOS and PFOA. The concentrations ranged from $42.5 \mathrm{ng} / \mathrm{L}$ for PFOS and $30.6 \mathrm{ng} / \mathrm{L}$ for PFOA. For the residential areas, the total concentrations of PFAS in runoff were $<30 \mathrm{ng} / \mathrm{L}$ and, with no individual PFAS concentration, was $>20 \mathrm{ng} / \mathrm{L}$. Similarly, urban stormwater samples have been reported to contain $2.6-26 \mathrm{ng} / \mathrm{L}$ of PFOS and 2.1-16 ng/L of PFOA, as the predominant perfluorinated compounds [35].

Urban stormwater also carries micropollutants attached to particles [36] including PFAS. High concentrations of PFAS are also found bound to particles in stormwater runoff that could not be explained by the solid-water partitioning or adsorption [34]. PFOS on the particulate matter was suspected to have originated from industrial/commercial products or inherent in the particles/debris (e.g., debris of textiles), entering the waste stream as PFOS-containing particles. It is likely that colloidal materials can transport a significant portion of PFAS in surface and subsurface waters.

\subsection{PFAS in Treated Wastewater}

The most frequently found PFAS compound in European wastewaters is PFOA [37]. PFOA was found not to be significantly removed by conventional engineered wastewater treatment processes [38] and some studies have reported higher PFOA concentrations in wastewater effluents than influents, presumably because of transformation of its precursor's compounds [32,39].

A median PFOA concentration of $27 \mathrm{ng} / \mathrm{L}$ was reported for a large number of global wastewaters [40]. Similarly, the results of the monitoring of 90 European wastewater treatment plants shows the maximum, mean, and median PFOA concentration to be $15,900,255$, and $12.9 \mathrm{ng} / \mathrm{L}$, respectively [37].

Irrigation using treated wastewater may potentially distribute PFAS in a diffuse manner and their impact on groundwater are not well understood. In water-stressed regions in Australia, the use of treated wastewater (referred to as recycled water) is an established practice and encouraged by regulators that are likely to be necessary into the foreseeable future [41]. Without appropriate processes that remove PFAS, they are likely present in wastewater effluents. Wastewater treatment facilities have been found to be ineffective in removing many PFAS [42-45]. Eriksson et al. [45] reported that precursor compounds caused an observed increase for PFAS and PFOA in water after wastewater treatment. Increases were reported for perfluorohexanoic acid (83\%), perfluorooctanoic acid $(28 \%)$, perfluorohexane sulfonic acid (37\%), and PFOS (58\%) had a net mass increase in all wastewater treatment plants. It was concluded that degradation of precursor compounds is a significant contributor to PFAS contamination in the environment. Reverse osmosis has been found to be necessary to provide a high level of PFAS removal [44]. Overall, these studies reveal the wide occurrence of PFAS in treated 
wastewaters internationally and may contribute to increased accumulation by species within the receiving environment [46] and influence the viability of water recycling via aquifers.

\section{Engineered Treatment of PFAS}

Engineered treatments can be integrated into the MAR system (Figure 1) as pre-treatment or post-recovery systems. MAR pre-treatment is usually adopted for operational reasons, e.g., to remove turbidity or nutrients and reduce the risk of clogging during the recharge stage (Figure 1) and to protect the receiving groundwater environment (aquifer). A number of engineered pre-treatment technologies have been evaluated for their efficiency to remove and/or destroy PFAS. Some of these elements may potentially be adopted with MAR as either a pre-treatment or post-treatment process (Figure 1). Figure 2 shows various possible technologies for treating PFAS-contaminated water, since more readers are referred to previously published reviews [47-49].

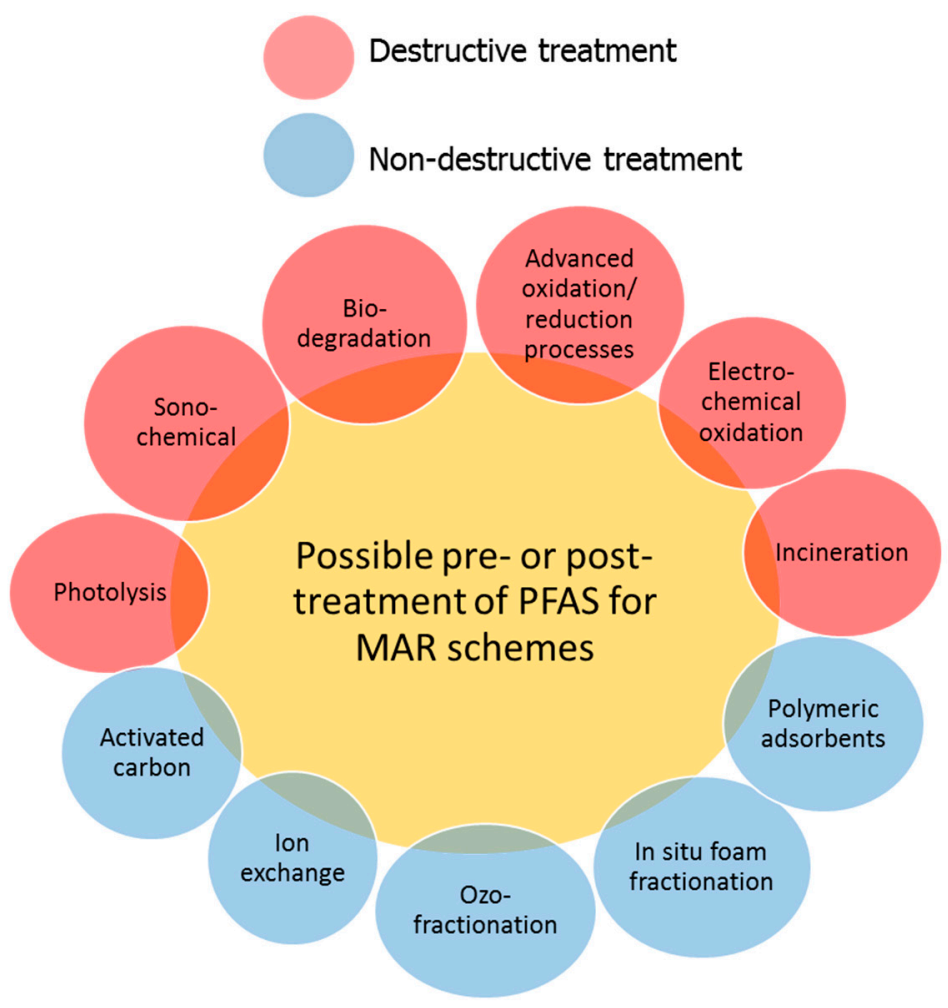

Figure 2. Possible PFAS pre-treatment or post-treatment technologies for MAR schemes (modified after Ross et al., [49]).

Given the unique chemical nature of PFAS such as thermal stability, surfactant property, and high solubility, many conventional remediation methods, including air stripping, thermal treatment, soil vapor extraction, and hydroxyl-based chemical oxidation are ineffective in treating PFAS [48]. Nevertheless, several established technologies have been considered for treating water contaminated by PFAS, especially PFOA and PFOS [47]. These technologies include sorption-treatment using granular activated carbon (GAC) and/or ion-exchange resins, high-pressure membrane filtration such as nano-filtration and reverse osmosis, chemical or advanced photochemical oxidation processes, and sonochemical decomposition using high frequency sound waves.

GAC and ion-exchange resins have been commonly used for removing PFAS from contaminated groundwater especially for pump-and-treat remediation [50]. Using GAC for PFAS removal has been suggested as a more economical method compared to others, and it is currently the most accepted remediation technology for groundwaters impacted by PFOS and PFOA [48]. However, even though using GAC as a sorbent would enable PFAS removal efficiencies of $>90 \%$, the sorption kinetics are 
typically faster for longer-chained PFAS [51]. Hence, GAC that is optimized for PFOS removal may not be suitable for removing shorter-chained PFAS [52]. There is concern that smaller chain PFAS (four or six carbons) are more vulnerable to break through a GAC medium within shorter time frames than their longer chain counterparts [48]. It has been reported that the pilot-scale GAC-adsorption plant adopted by 3M Cottage Grove Facility in Minnesota, USA required frequent thermal regeneration of the GAC because of this problem [48]. Using GAC for PFAS removal should be considered as an intermediate remedial step, since it should be followed by processes for PFAS destruction and sorbent reuse. Otherwise, stockpiling of spent GAC will become a critical hazardous waste management issue, given the highly persistent nature of PFAS. Storage space is often limited at MAR schemes, and the disposal of PFAS contaminated GAC at landfills may pose secondary pollution risks to the environment surrounding the landfill when leaching to groundwater. Therefore, methods that can efficiently destroy PFAS in both contaminated water and stockpiled GAC are highly desirable.

Others demonstrated that nanofiltration could effectively remove PFOA from a spiked groundwater sample [53]. They tested three different concentrations of PFOA (5, 50, and $100 \mu \mathrm{g} / \mathrm{L})$ and found that the removal efficiency was generally higher with higher PFOA concentration (increasing from $97 \%$ to $99 \%$ ). With a higher PFAS concentration, reverse osmosis could facilitate $99 \%$ removal of PFOS (ranging from 500 to $150,000 \mu \mathrm{g} / \mathrm{L}$ ) [54] and a combination of reverse osmosis and nanofiltration could facilitate $99 \%$ removal of PFOS and $90 \%$ to $99 \%$ removal of PFOA $(10,000 \mu \mathrm{g} / \mathrm{L})$ during four days of treatment [55]. However, albeit having high removal efficacies $(99 \%)$, the method was unable to guarantee a treated effluent with PFAS lower than the interim draft guideline values (e.g., $0.23 \mathrm{ng} / \mathrm{L}$ for PFOS, and $19 \mu \mathrm{g} / \mathrm{L}$ for PFOA for Australian aquatic ecosystems: freshwater guideline values). Hence, the use of such a method needs careful consideration. It was also noted that accumulation (fouling) of PFAS on the reverse osmosis and nanofiltration membranes would cause notable flux reduction in the filtration process [55]. Moreover, current nanofiltration systems suffer from a low water recovery (ranging from $75 \%$ to $80 \%$ ) in the presence of high levels of scale-forming inorganic compounds containing calcium, magnesium, and silica (as silicic acid) in groundwater [56,57]. This implies the production of a significant volume of waste stream (brine) that requires further treatment prior to disposal.

Various chemical/advanced photochemical oxidation and sonochemical methods have been evaluated for PFAS destruction (Table 1). Advanced oxidation processes using ozone $\left(\mathrm{O}_{3}\right), \mathrm{O}_{3} / \mathrm{UV}$, $\mathrm{O}_{3} / \mathrm{H}_{2} \mathrm{O}_{2}$, and $\mathrm{H}_{2} \mathrm{O}_{2} / \mathrm{Fe}^{2+}$ (Fenton's reagent) were unsuccessful in degrading PFOA and PFOS at mg/L (ppm) concentrations. Direct UV irradiation at $254 \mathrm{~nm}$ did not remove PFOA [47]. Reaction rates were low at relatively low temperatures (e.g., $40^{\circ} \mathrm{C}$ ), and activation at higher temperature was required to accelerate a reaction $\left(70-90^{\circ} \mathrm{C}\right)$ [48]. A combination of UV ( $\left.\lambda_{\max } 254 \mathrm{~nm}\right)$ and Fenton's reagent was reported to efficiently degrade PFOA [58], but the method requires chemical additions and increases the iron content of the water. 
Table 1. Summary of laboratory-scale test results for selected treatment processes evaluated for PFAS destruction.

\begin{tabular}{|c|c|c|c|c|}
\hline Process & $\begin{array}{l}\text { Destruction } \\
\text { Mechanism }\end{array}$ & Condition & PFAS Destruction & Reference \\
\hline $\begin{array}{l}\text { Light-activated } \\
\text { persulfateS }{ }_{2} \mathrm{O}_{8}{ }^{2-}\end{array}$ & Oxidative & $\begin{array}{l}\text { Light-activated persulfate at } 50 \mathrm{mM} \text {, } \\
\text { and } 4 \mathrm{~h} \text { of radiation }\end{array}$ & 100\% (PFOA 559 mg/L) & [59] \\
\hline $\begin{array}{l}\text { Heat-activated } \\
\text { persulfate }\end{array}$ & Oxidative & $\begin{array}{l}\text { Persulfate at } 50 \mathrm{mM} \text {, activated by } \\
\text { heating at } 80^{\circ} \mathrm{C} \text { for } 6 \mathrm{~h}\end{array}$ & $\begin{array}{l}\text { PFOA decreased from } 155 \text { to } \\
0.63 \mathrm{mg} / \mathrm{L}\end{array}$ & {$[60]$} \\
\hline $\begin{array}{l}\text { Fenton's } \\
\text { reagent-activated } \\
\text { persulfate }\end{array}$ & Oxidative & Not available & $>97.5 \%$ PFOS destruction & {$[61]$} \\
\hline $\begin{array}{l}\mathrm{H}_{2} \mathrm{O}_{2} \text { activated } \\
\text { persulfate }\end{array}$ & Oxidative & Not available & $>97.5 \%$ PFOS destruction & {$[61]$} \\
\hline UV-Fenton & Oxidative & $\begin{array}{c}\mathrm{H}_{2} \mathrm{O}_{2} 30.0 \mathrm{mM}, \mathrm{Fe}^{2+} 2.0 \mathrm{mM}, \mathrm{pH} 3.0 . \\
\text { A } 9 \text { W UV lamp }\left(\lambda_{\max }=254 \mathrm{~nm}\right)\end{array}$ & $\begin{array}{c}>95 \% \text { PFOA destruction } \\
\text { from } 8.2 \mathrm{mg} / \mathrm{L} \text { and } \\
\text { defluorination efficiency of } \\
53.2 \%\end{array}$ & [58] \\
\hline $\begin{array}{l}\text { Subcritical water } \\
\text { catalyzed by } \\
\text { zero-valent iron }\end{array}$ & Oxidative & $\begin{array}{l}\text { Subcritical water }\left(350^{\circ} \mathrm{C}\right) \text { catalyzed } \\
\text { by zero-valent iron. Adsorption of } \\
\text { PFOS onto } \mathrm{Fe}_{3} \mathrm{O}_{4} \text { precipitate } \\
\text { followed by oxidation to } \mathrm{O}_{2} \text { and } \mathrm{F}^{-} \text {. }\end{array}$ & $\begin{array}{l}97.6-99.4 \% \text { removal of PFOS } \\
\text { to below }<1.1 \mathrm{mg} / \mathrm{L}\end{array}$ & [63] \\
\hline Sonochemical & Sonolysis & $\begin{array}{l}\text { Solutions containing various PFOS } \\
\text { concentrations }(65 \mu \mathrm{g} / \mathrm{L} \text { to } 13,100 \\
\mu \mathrm{g} / \mathrm{L}) \text { were treated with ultrasonic } \\
\text { irradiation (frequency } 505 \mathrm{kHz} \text {, at } \\
\text { power density } 187.5 \mathrm{~W} / \mathrm{L})\end{array}$ & $\begin{array}{l}73 \% \text { degradation of PFOS } \\
\text { during } 120 \text { min treatment }\end{array}$ & {$[64]$} \\
\hline
\end{tabular}

Sonochemical treatment appears to be a practical and scalable method to treat PFAS [48]. It promises to be used as a destructive method to destroy PFAS in PFAS-loaded sorbents (e.g., spent GAC). The method is based on the application of acoustic irradiation to the contaminated medium (e.g., treated wastewater or PFAS contaminated spent GAC). The ultrasound waves collapse the bubbles in the aqueous phase (a process known as cavitation), which increases vapor temperatures to incinerator level (average $4727^{\circ} \mathrm{C}$ ) and pressures $(-97,000 \mathrm{kpa}$ ) within a very short time (nano second), which causes pyrolysis and combustion of the contaminants at the bubble-water interface [47]. Radicals (e.g., $\mathrm{HO}^{\bullet}$ ) are also generated within the bubble from the cleavage of $\mathrm{H}_{2} \mathrm{O}$ and $\mathrm{O}_{2}$ to react with or destroy the contaminants. Sonochemical destruction has been successfully demonstrated in a pilot-scale high-power sonochemical treatment unit $(4 \times 4 \mathrm{~kW})$ for the treatment of the solid matrix (e.g., soil slurries contaminated with a range of persistent organic pollutants, including hexachlorobenzene, chlordane, endosulfan, tetrachloronaphthalene, DDT, lindane, and 2,4,5-trichlorophenoxyacetic acid) [65]. The treatment was highly efficient, with more than $90 \%$ of the organic contaminants removed within only a few minutes, which allows a projected treatment of contaminated soil slurry of up to 2.5 tons per day. While the sonochemical technique appears promising for treating PFAS contaminated materials on a large scale, incomplete destruction of PFAS is currently perceived as a drawback. For instance, the degradation rates of PFOS and PFOA in a sonochemical treatment of a landfill groundwater sample (140 minutes of hydraulic retention time at an ultrasonic frequency of $354 \mathrm{kHz}$, and initial PFOS and PFOA concentrations of $100 \mu \mathrm{g} / \mathrm{L}$ ) decreased by $61 \%$ and $56 \%$, respectively, due to the matrix effect of other organic constituents present in the groundwater [66]. A recent study also found that polyfluoroalkyl compounds (e.g., 6:2 fluorotelomer sulfonate) were less amenable for sonochemical destruction than perfluoroalkyl analogues (PFOA and PFOS), and the rate of defluorination reduced with a decreasing degree of fluorination [67]. Moreover, the presence of particulate matter, such as GAC, may alter the effectiveness of ultrasound treatment [68]. Given the recent emphasis favoring the combination of different PFAS treatment technologies in treatment trains 
to maximize overall PFAS destruction efficacies [69]. It seems essential to explore a possible coupling of the sonochemical treatment with alternative methods to maximize the overall PFAS destruction in the contaminated media (both reverse osmosis and nanofiltration reject streams and GAC).

\section{Recharge of the Aquifer}

Aquifer recharge generally occurs by direct injection into the aquifer (saturated zone) or after infiltration through the unsaturated zone (Figure 1). Recharging of an aquifer with stormwater or treated wastewater requires adherence to local environmental legislation for protecting groundwater systems. PFAS contamination can be considered a significant risk due to its known persistence and potential for bioaccumulation and toxicity $[10,13,70]$. From a risk management perspective, to demonstrate compliance, MAR operators will need to have an understanding of the PFAS concentrations in the recharge water (Section 3) and, potentially, the nature and location of PFAS sources within the source capture zone. In MAR schemes, risk assessment and management require an understanding of the environmental values of the aquifer that may be impacted by the recharge, as well as both on-site and off-site pathways to environmental receptors. Risk management measures for PFAS may include catchment management to reduce the risk of PFAS contamination in the recharge water and engineered (Section 4) or natural treatment systems (Section 6). This will require undertaking water quality monitoring to determine PFAS concentrations and the effectiveness of management measures implemented and ensuring environmental guideline values are met. Currently, in Australia, the relevant environmental guideline value is dependent on the environmental value of the receiving environment (Table 2) [19].

Table 2. Australian draft guidelines relevant to typical environmental values of aquifers and downstream environmental receptor. Aquatic ecosystems: freshwater and marine water guideline values [19,71].

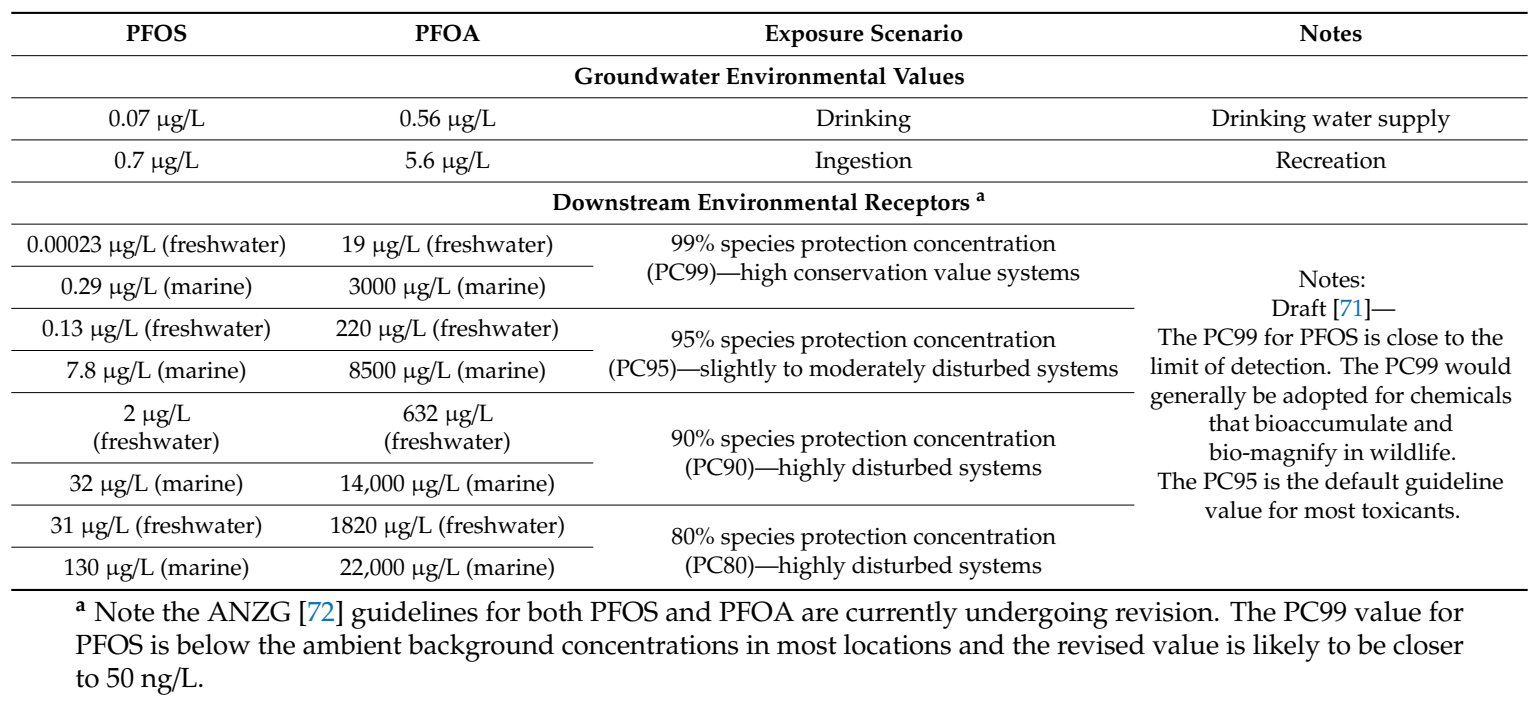

Health-based and ecological-based guideline values for water (Table 2) provide primary guidance on the suitability of PFAS-contaminated water for reuse. The reuse also must not breach environmental and/or health laws such as those pertaining to the contamination of drinking water, groundwater, stormwater, and soil. These guideline values must be considered along with the potential for water to impact groundwater or aquatic ecosystems. Based on the recent guidelines from Heads of EPAs of Australia and New Zealand [19] reuse of PFAS-contaminated water must not be undertaken until consultation with the relevant regulators has taken place, since reuse activities may require specific approval. Acceptable reuse options could include irrigation of non-edible crops, dust suppression, MAR, and industrial process water. Where reuse involves the discharge of PFAS-contaminated water to land, the risk assessment should not only consider the potential for PFAS transport to 
off-site sensitive receptors, but also the potential for long-term build-up of the total PFAS mass in the receiving soils, groundwater, and plants. Where water is to be used for managed aquifer recharge and recovery, water quality criteria should be derived with consideration of the receiving aquifer (i.e., protected environmental values, sedimentary/confined aquifer versus fractured rock, potential for future beneficial uses, and long-term transport) [19].

Currently, the proposed 99th percentile species protection concentration (Table 2) may be below the ambient background concentration of PFAS in source waters. In these instances, the 80th percentile of background concentrations for reference sites with low levels of human impact should be adopted. These will be more useful as a default MAR guideline value where this is less than the reliable background concentration. Other environmental regulators use drinking water guideline values (Table 2) as default values for environmental protection. For example, in Australia, human health-based guidance values are derived from published Tolerable Daily Intake (TDI) for chemicals. For drinking water, these TDI values are used to investigate and assess potential human health risks and to set human health-based guidelines based on the relationship: Drinking water guideline value $(\mathrm{mg} / \mathrm{L})=$ TDI $\left(\mathrm{mg} / \mathrm{kg}_{\mathrm{bw}} /\right.$ day $) \times \mathrm{bw}(\mathrm{kg}) \times \mathrm{P} / \mathrm{V}(\mathrm{L} /$ day $)$.

In this case, the TDI is an estimate of the daily amount of PFAS that can be ingested over a life time that is considered safe, where bw is bodyweight (assumed average bodyweight of an Australian adult, $70 \mathrm{~kg}$ ), $\mathrm{V}$ is the volume of water consumed (assumed to be $2 \mathrm{~L} /$ day for drinking water), and $\mathrm{P}$ is the proportion of PFAS derived from water compared to other exposure pathways such as food ( $\mathrm{P}$ is variable, but the default value is $10 \%$, i.e., $\mathrm{P}=0.1)$ ). In Australia, the TDI is $0.02 \mu \mathrm{g} / \mathrm{kg}_{\mathrm{bw}} / \mathrm{d}$ for PFOS and $0.16 \mu \mathrm{g} / \mathrm{kg} \mathrm{bw} / \mathrm{d}$ for PFOA (Food Standards Australia New Zealand (FSANZ) [72]. The results yield drinking water guideline values for PFOS $(0.07 \mu \mathrm{g} / \mathrm{L})$ and PFOA $(0.56 \mu \mathrm{g} / \mathrm{L})$ [73]. For recreational waters, values of $0.7 \mu \mathrm{g} / \mathrm{L}$ (PFOS) and $5.6 \mu \mathrm{g} / \mathrm{L}$ (PFOA) have been adopted [73]. The use of the different guideline values for environmental management of PFAS presents some challenges for effective risk management and regulation of PFAS in MAR.

\section{Subsurface Processes and PFAS in MAR}

Aquifers have well recognized advantages with respect to ongoing natural treatment of the water prior to recovery [74]. Aquifers do not, in general, behave like inert systems, but rather as biogeochemical reactors that change the quality of water recovered from the quality of the water source used for recharge. Understanding these subsurface water quality changes is necessary to evaluate the suitability of the recovered water for its intended use and any requirement for post-treatment prior to recovery.

To date, there have been several studies on the effect of subsurface storage on the degradation and sorption of organic micropollutants in both full-scale MAR systems [74] as well as reviews [75]. Hydrogeochemical characteristics of the MAR system such as redox potential may have a profound effect on the degradation rate of organic micropollutants [75,76]. Generally, the potential for aquifer treatment is most often investigated in laboratory studies either as a batch $[77,78]$ or column studies $[79,80]$. However, unlike most other micropollutants found in urban stormwater or treated wastewater, PFAS are resistant to biodegradation [81] and photodegradation [82], are water soluble [83], and their partitioning to sediments with a low organic fraction (i.e., low $f_{o c}$ ) is low [25]. Because of these properties, PFAS can potentially be transported long distances in the subsurface during MAR and affect other receiving environments such as groundwater-dependent ecosystems. PFAS plumes extending for $10^{\prime} \mathrm{s} \mathrm{kms}$ from source areas have been observed in some locations (e.g., Oakey [84]) and Williamstown [85], which indicates that PFAS compounds can be highly mobile in some groundwater aquifers.

The sorption behavior of a range of PFAS was not well explained by the traditionally used single bulk sediment property parameters such as organic carbon content [86]. Hence, multiple regression models are needed to better explain the sorption behavior of a number of PFAS, which highlights that organic carbon, $\mathrm{pH}$, and clay content are properties with an effect on the sorption capacity of soils [86]. 
Adsorption on ferric oxic minerals, rather than sorption to organic carbon, is also a potentially important mechanism [86]. At higher $\mathrm{pH}$, sorption is generally controlled by the aquifer organic carbon content while, at $\mathrm{pH}$ near neutral, sorption is controlled by electrostatic interactions with mineral surfaces [87]. Sorption has also been reported to increase with increasing soluble calcium concentrations, which also suggests electrostatic interactions are involved [88]. Sorption by an electrostatic interaction can be easily desorbed by a change in solution chemistry [89].

On the other hand, previous studies also suggest that PFAS transformations may be feasible in the aquifer. However, this transformation may result in either a reduction or increase in PFAS concentration. For example, that exposure of urban stormwater to oxidation processes resulted in a $69 \%$ increase in the concentrations of their precursors, which includes perfluoroalkyl carboxylic acids from unidentified precursor compounds [35]. Similarly, a substantial increase in PFAS concentrations during wastewater treatment plants has been observed [45]. In addition to oxidation processes, microbial activity has been suggested to increase the concentrations of the precursor compounds, perfluoroalkyl carboxylic acids, and perfluoroalkyl carboxylic sulfonic acids [35].

This transformation potential has also been shown for PFOS concentrations in Tokyo groundwater, which were consistently higher than PFOS concentrations measured in wastewater and urban runoff (the two most likely sources of contamination) [33]. A soil column test confirmed the production of PFOS from its precursor compounds [32]. Hence, polyfluorinated substances present in recharge water could potentially be transformed to the perfluoroalkyl acids by natural aquifer processes leading to an increase in the concentration of these compounds via MAR. Furthermore, the PFAS compositions of some products that likely contain structurally unknown precursor compounds [35]. This could present a regulatory issue for current and new MAR schemes especially if there is an apparent increase in PFAS in the recovered water. Additional post-treatment may then be required in addition to any pre-treatment to meet human health requirements for specific end uses.

MAR can be undertaken in a range of hydrogeological and geochemical settings (e.g., Table 3) and, as such, every MAR system could potentially have a varied effect in terms of natural PFAS treatment.

\section{Key Potential Processes in the Natural Attenuation of PFAS in MAR}

Due to the temporal and spatial variability in MAR systems, there are a variety of potential parameters that influence the attenuation of PFAS in MAR systems. Generally, dilution will reduce the concentration of PFAS during MAR but is not considered a form of attenuation. The most important attenuation mechanism for MAR treatment of PFAS is adsorption. This mechanism is governed by PFAS physicochemical properties (e.g., $\mathrm{K}_{\mathrm{oc}}$, Henry's law constants, polarity) as well as the MAR systems hydrogeological site-specific conditions (aquifer type, temperature, redox state, and mineralogy) of the MAR system. Table 3 shows some MAR system characteristics. 
Table 3. MAR system hydrogeological and geochemical characteristics.

\begin{tabular}{|c|c|c|c|c|c|c|c|c|c|c|c|c|}
\hline Aquifer Type & $\begin{array}{c}\text { Recharge } \\
\text { Type }\end{array}$ & Porosity & Mineralogy & $\begin{array}{c}\text { Organic } \\
\text { Carbon (\%) }\end{array}$ & $\begin{array}{c}\text { Clay } \\
\text { Content (\%) }\end{array}$ & $\begin{array}{c}\text { CEC } \\
\text { (meq/100g) }\end{array}$ & $\mathrm{pH}^{*}$ & $\begin{array}{c}\mathrm{Fe}^{2+} \\
(\mathrm{mg} / \mathrm{L})\end{array}$ & $\begin{array}{c}\mathrm{Ca}^{2+} \\
(\mathrm{mg} / \mathrm{L})\end{array}$ & $\begin{array}{l}\text { Redox } \\
\text { State }\end{array}$ & $\begin{array}{c}\text { Temperature } \\
\left({ }^{\circ} \mathrm{C}\right)\end{array}$ & Reference \\
\hline limestone & injection & 0.47 & $\begin{array}{l}\text { calcite }(74 \%), \text { quartz }(18 \%), \\
\text { ankerite }(5 \%), \text { hematite, } \\
\text { microcline, albite }\end{array}$ & 0.2 & & 2.0 & 7.3 & 0.56 & 152 & anoxic & 26 & {$[90,91]$} \\
\hline limestone & injection & 0.34 & $\begin{array}{l}\text { calcite }(65 \%) \text {, quartz }(22 \%), \\
\text { ankerite, goethite, hematite, } \\
\text { pyrite, albite, microcline }\end{array}$ & $<0.5$ & & 1.8 & 6.9 & 1.54 & 135 & anoxic & 26 & {$[92,93]$} \\
\hline limestone & injection & - & $\begin{array}{l}\text { quartz }(55 \%) \text {, calcite }(40 \%), \\
\text { chlorite, smectite, K-feldspar, } \\
\text { pyrite, hematite, magnetite }\end{array}$ & - & - & - & 7.6 & - & 146 & anoxic & - & [94] \\
\hline alluvium & infiltration & - & $\begin{array}{l}\text { quartz (20-60\%), albite (4-12\%), } \\
\text { orthoclase, kaolinite, smectite, } \\
\text { calcite, hematite }\end{array}$ & $<0.1-4$ & $1-58$ & $2-27$ & 6.9 & - & 242 & oxic & - & {$[91,95,96]$} \\
\hline alluvium & injection & - & $\begin{array}{l}\text { quartz }(>60 \%) \text {, goethite, } \\
\text { smectite, kaolinite }\end{array}$ & $<0.4$ & - & 4.4 & 7.8 & $<0.5$ & 32 & anoxic & 19 & [74] \\
\hline sandstone & injection & - & $\begin{array}{c}\text { quartz (72\%), k-feldspar (24\%), } \\
\text { pyrite Na-feldspar }\end{array}$ & 0.32 & $<1 \%$ & - & $6.5-7.3$ & $5-20$ & $11-21$ & anoxic & - & {$[80,97]$} \\
\hline $\begin{array}{c}\text { fractured } \\
\text { siltstone-sandstone }\end{array}$ & injection & 0.22 & $\begin{array}{l}\text { quartz }(48-73 \%), \text { kaolinite } \\
(13-23 \%) \text {, muscovite, siderite, } \\
\text { chlorite, pyrite. }\end{array}$ & $<0.3$ & - & 3.2 & 7.7 & - & - & anoxic & - & {$[93,98]$} \\
\hline $\begin{array}{l}\text { calcareous sand } \\
\text { over limestone }\end{array}$ & infiltration & $\begin{array}{c}0.35 \\
\text { (unsat } \\
\text { zone) }\end{array}$ & $\begin{array}{l}\text { quartz, calcite, microclilne, } \\
\text { anorthite, iron oxides }\end{array}$ & - & $<2 \%$ & - & 7.0 & 0.44 & 99 & oxic & 22 & [99-101] \\
\hline
\end{tabular}

* concentration in ambient groundwater, Fe-soluble. 
Microbial degradation may potentially offer an attractive option for PFAS remediation during MAR in the subsurface, since microbial processes generally do not require intensive energy and operate under ambient or mild conditions [69]. In principle, given their relatively high oxidation states, PFAS could be used as electron acceptors for anaerobic microorganisms to meet their energetic requirement [51,102]. However, under natural conditions, biodegradation of PFAS is extremely difficult because of the very stable carbon-fluorine (C-F) bonds [102].

PFAS biodegradation can be evaluated under natural conditions by use of quantitative structure-biodegradability relationships. For example, reported values were between -1.19 and 0 in BIOWIN where a probability $>0.5$ indicates fast biodegradation and a probability $<0.5$ indicates slow biodegradation [103]. These indicated that there would be little to no expected biotransformation of PFAS during MAR regardless of the specific microbial community, redox conditions, temperature, and retention times of the scheme [103]. Similarly, PFAS attenuation by volatilization, photolysis, or hydrolysis is also expected to be of minor importance for PFAS during MAR.

However, less information is available on Gibbs-free energy values of fluorinated compounds as compared to chlorinated compounds. The thermodynamic calculations show that, under standard conditions with $100 \mathrm{kPa}$ of hydrogen gas $\left(\mathrm{H}_{2}\right)$, the reductive defluorination should be exergonic and, hence, feasible (Table 4) [104]. Accordingly, under conditions with elevated $\mathrm{H}_{2}$ partial pressure, microorganisms may be able to obtain energy for growth by reductively de-fluorinating PFAS. However, in natural environments such as the aquifer subsurface, the $\mathrm{H}_{2}$ partial pressure is typically $-10,000$ times lower, which significantly diminishes the energetics of the reactions.

Table 4. Gibbs-free energy values for reductive dehalogenation of selected fluorinated aromatic and aliphatic compounds as well as their chlorinated analogues.

\begin{tabular}{|c|c|c|}
\hline \multirow{2}{*}{ Reaction $^{a}$} & \multicolumn{2}{|c|}{$\Delta \mathrm{G}(\mathrm{kJ} / \mathrm{mol})$} \\
\hline & Defluorination & De-Chlorination \\
\hline 2-Halobenzoate $+\mathrm{H}_{2} \rightarrow$ Benzoate $+\mathrm{H}^{+}+$halide ${ }^{-}$ & -132 & -145 \\
\hline 3-Halobenzoate $+\mathrm{H}_{2} \rightarrow$ Benzoate $+\mathrm{H}^{+}+$halide $^{-}$ & -138 & -137 \\
\hline 4-Halobenzoate $+\mathrm{H}_{2} \rightarrow$ Benzoate $+\mathrm{H}^{+}+$halide ${ }^{-}$ & -142 & -144 \\
\hline Halomethane $\rightarrow$ Methane $+\mathrm{H}^{+}+$halide ${ }^{-}$ & -156 & -164 \\
\hline Dihalomethane $\rightarrow$ Halomethane $+\mathrm{H}^{+}+$halide $^{-}$ & -107 & -161 \\
\hline Trihalomethane $\rightarrow$ Dihalomethane $+\mathrm{H}^{+}+$halide ${ }^{-}$ & -85 & -170 \\
\hline Tetrahalomethane $\rightarrow$ Trihalomethane $+\mathrm{H}^{+}+$halide ${ }^{-}$ & -89 & -188 \\
\hline
\end{tabular}

${ }^{a}$ All calculations used the following standard conditions: $\mathrm{T}=298.15 \mathrm{~K}, \mathrm{pH} 7$, methane, and $\mathrm{H}_{2}$ in the gas phase at $1 \mathrm{~atm}$, benzoates, and halides in the aqueous phase at $1 \mathrm{M}$. (Adapted from Parsons et al., 2008, [105]).

Given the unlikelihood of biodegradation of PFAS in the aquifer, this leaves adsorption on the aquifer-sediment surface as the most promising attenuation process for PFAS during the MAR storage step. The amount of sorption of PFAS also affects its travel time in the subsurface prior to recovery. Irreversible sorption to minerals and aquifer sediments, potentially followed by mineralization, could permanently remove PFAS from the recharged water. Sorption of organic chemicals has previously been investigated by means of a dimensionless retardation coefficient $(R)$, which involves the ratio of the breakthrough times of the transport of an organic chemical compared to the transport of a non-reactive conservative tracer like bromide. Sorption can occur either by hydrophobic attraction between soil organic matter and non-polar organic chemicals (known as hydrophobic partitioning) or by the attraction to mineral surfaces by electrostatic forces (physical sorption) [105]. The latter is most relevant for MAR schemes involving direct injection into aquifers with low organic carbon content, whereas infiltration schemes may interact with both organic and inorganic surfaces.

The chemical and physical retardation mechanisms are influenced by a wide range of variables, soil water distribution coefficients, or sorption coefficients, which are related directly to the aquifer sediment character. Several studies demonstrated that sorption of ionizable compounds like PFAS to aquifer sediments due to electrostatic interactions is highly influenced by factors like $\mathrm{pH}$, calcium 
content, mineral surface characteristics such as iron oxides, cation exchange capacity, and the presence of clay minerals [106-108]. However, due to the interconnectedness of multiple factors, inconsistencies in retardation for individual organic chemicals are frequently reported. For example, the determined R-values for BPA (1.2) and 17- $\alpha$-ethinylestradiol (1.1) imply minimal sorption [103]. However, these values differ significantly among R-values for BPA [26] and 17- $\alpha$-ethinylestradiol [44], respectively, which implies a very significant adsorption.

To date, there have not been many similar studies for PFAS on adsorption in aquifer sediments. If a large variability in R-values is reported, this indicates the need to establish PFAS retardation factors or sorption coefficients for each MAR scheme independently and broad aquifer types may not be suitable to determine a potential for sorption. Aquifer treatment will be dominated by the local hydrogeochemical properties of the specific MAR scheme. Furthermore, since PFAS poses unique physicochemical properties (a hydrophilic head, hydrophobic tail, and strong polarized carbon-fluorine bonds) it may be difficult to predict their distribution in MAR systems using the more commonly described chemical partitioning models [87]. PFAS, which interacts minimally with the aquifer sediments, would also be expected to exhibit shorter retention times in the subsurface and possibly be more difficult to degrade than similar compounds that interact more strongly with the sediments.

Factors affecting electrostatic interaction will be crucial for PFAS sorption to mineral surfaces. A positive surface charge is favorable for electrostatic interaction between the mineral surface and the negative PFAS functional group [89]. The mineral phases in Table 5 are listed in order of decreasing potential for adsorption based on expected positive charge at a neutral $\mathrm{pH}\left(\mathrm{pH}_{\mathrm{ZPC}}>7\right)$. Available sorption coefficients for PFAS are reported where available.

Table 5. Sorption coefficients, surface area, and point of zero charge for mineral phases relevant to MAR. Minerals are listed in order of decreasing potential for sorption of PFAS.

\begin{tabular}{ccccc}
\hline Mineral & Point of Zero Charge $\left(\mathbf{p H}_{\mathrm{ZPC}}\right)$ & $\mathbf{K d} \mathbf{( L / k g})$ & Surface Area $\left(\mathbf{m}^{2} / \mathbf{g}\right)$ & Reference \\
\hline goethite & $7.5-9.5$ & 7.88 & 58 & {$[107,108]$} \\
$\begin{array}{c}\alpha-\mathrm{FeOOH}) \\
\text { calcite }\end{array}$ & $8-9.5$ & & $1-2$ & {$[109]$} \\
alumina & 6 & & & {$[89]$} \\
kaolinite & 4.6 & 5.31 & 10 & {$[107]$} \\
silica & 2 & no sorption & & {$[89]$} \\
\hline
\end{tabular}

\section{Recovery of Water from MAR}

While there are many configurations of MAR schemes [28], water is generally recovered via an extraction well, as shown for both infiltration schemes and direct injection methods. However, this is not always the case. For some configurations of MAR, the recharged water remains in the environment where water is recharged for the ecosystem support to a groundwater dependent ecosystem or for saltwater intrusion barriers. It is for these examples where pre-treatment of the recharge water is particularly important to meet the required ecosystem protection criteria (Table 2). Water recovered from the MAR scheme is also likely to be a mixture of the native groundwater and recharged water presenting other potential issues for water quality such as the mobilization of metals from aquifer sediments or salinity if the MAR scheme is in a brackish aquifer.

\section{Post Treatment of Recovered Water}

Differing end uses (e.g., drinking water and recreation) have different published guidelines values associated with them and, hence, different objectives need to be adopted for the post-treatment of the MAR step. Using the same approach as used to derive drinking water guideline values, a maximum permissible PFAS concentration can be calculated for different end uses based on the tolerable daily intake and the degree of daily exposure. Several examples are given in Table 6 for a variety of common third-pipe uses for urban water. The exposure scenarios via the use of groundwater contaminated with 
PFAS for the irrigation of edible crops, drinking water for livestock, or via the consumption of fish from waters whose influx from groundwater contains measurable concentrations of PFAS. Therefore, these exposure scenarios need a special human health-based assessment and are not included in this paper. The values are to be viewed with caution and are not guidelines. Furthermore, no provision has been made for irrigation of food crops due to the potential for bioaccumulation of PFAS.

Table 6. Selected MAR recovered water uses, PFOS, and PFOA concentrations that meet Australian tolerable daily intake values for water reuse.

\begin{tabular}{|c|c|c|c|c|c|}
\hline & & Dose $(\mathrm{mL})$ & $\begin{array}{l}\text { Frequency } \\
\text { (n/year) }\end{array}$ & PFOS $(\mu \mathrm{g} / \mathrm{L})$ & PFOA $(\mu \mathrm{g} / \mathrm{L})$ \\
\hline \multirow[t]{3}{*}{ Garden irrigation $^{1}$} & Ingestion of sprays & 0.1 & 90 & 700 & 5600 \\
\hline & Routine ingestion & 1 & 90 & 70 & 560 \\
\hline & Accidental ingestion & 100 & 1 & 0.7 & 5.6 \\
\hline Municipal irrigation & Ingestion & 1 & 50 & 490 & 3920 \\
\hline Golf course irrigation & Ingestion & 1 & 33 & & \\
\hline Toilet flushing & Ingestion of sprays & 0.01 & 1100 & 7000 & 56,000 \\
\hline Washing machine use & Ingestion of sprays & 0.01 & 100 & 7000 & 56,000 \\
\hline Industrial (dust suppression) & Routine ingestion & 1 & 90 & 70 & 560 \\
\hline Car washing & Ingestion and Inhalation & 20 & 50 & 3.5 & 28 \\
\hline Fishing activity & Ingestion & 3 & 18 & 23 & 187 \\
\hline
\end{tabular}

It can be seen that all of the derived maximum values for different end-uses based on TDI described in Table 6 are higher than the published guideline values used to manage risks to human health (for drinking water) and the environment. This reflects the different risks based on the much lower potential human exposure for the different end uses. However, the use of these values has the potential to cause confusion in the community. Therefore, clear and timely communication on PFAS, their fate, and impacts will be critical in the management of PFAS in MAR schemes. Post-treatment technologies available are very similar to those described for pre-treatment above. The objectives of the post-treatment technologies adopted would need to be tailored to the required end-use.

\section{End Use of Water Recovered from MAR}

Water recovered from MAR systems supports a variety of end uses including: ecosystem protection, saltwater intrusion barriers, horticulture, agriculture, industrial, toilet flushing, urban green space irrigation, and drinking water [28]. Some studies have shown that vegetables and grains, which have been grown on agricultural lands that were irrigated with PFAS contaminated water can accumulate these compounds [111,112]. These short-chain compounds had a greater uptake potential by plants than longer chain PFAS and short chain sulfonates [113]. Currently, the behavior of short-chain carboxylic compounds in aquifer and their potential to be accumulated in edible plants via irrigation of contaminated groundwater is not fully understood. Acceptance of the recovered water for the end use will depend on the way in which information is conveyed to the community. It is critical to build trust between MAR operators, regulators, and the larger community for MAR systems to be sustainable and well accepted. Because PFAS is now detected in almost all environments including groundwater [8,114], MAR operations will need to communicate and manage risks associated with PFAS. Like many wastewater treatment plant discharges, PFAS will likely remain present in waters recovered from MAR systems. In the case of wastewater treatment plant discharges to coastal environments, elevated PFAS concentrations occur in fish collected nearer the outfalls and that risk must be communicated. Where the data suggest that PFAS concentrations in MAR-directed waters present a risk to human health or the environment for a given end use, information should be presented on how the community can minimize their exposure to decrease risk. This will require effective collaboration between all stakeholders in the MAR scheme, which will be critical to successful communication and engagement with communities. The environmental and human health regulators should be involved from the outset in planning and delivering communication and engagement activities. Regulators 
should act as an accessible source of information for the community and ensure that the MAR operators undertake appropriate engagement activities in accordance with the legislation. These steps will help to ensure that communication and engagement about PFAS and MAR is evidence-based, consistent, and accessible to the public.

\section{Conclusions}

The prediction of the fate of PFAS in urban stormwater and treated wastewater during MAR is important since PFAS are widely used, persistent, and have potential impacts on human health and the environment. PFAS concentrations may increase during MAR as a result of degradation of precursor compounds, so regulation may be problematic. PFAS can also potentially be transported long distances in the subsurface during MAR. To date, there are insufficient data to determine if PFAS can be degraded by natural processes or retained in the aquifer and, therefore, suitable pre-treatment or post-treatment technologies will need to be employed depending upon the end use of the recovered water for achieving economic efficiency and environmental sustainability. Options for PFAS removal through use of engineered systems in conjunction with MAR were discussed. Effective communication between the community and the key stakeholders is crucial to achieve community support for MAR schemes.

Author Contributions: D.P. conceived and designed the study. J.V. contributed to the geochemistry aspects. A.K. contributed to the human health risk assessment aspects. K.Y.C. and A.H.K. contributed to the PFAS pre-treatment and degradation aspects of the paper. S.S. contributed to the marine ecology aspects.

Funding: This research received no external funding.

Acknowledgments: The authors acknowledge CSIRO Land and Water for continued support of Managed Aquifer Recharge research.

Conflicts of Interest: The authors declare no conflict of interest.

\section{References}

1. Kauck, E.A.; Diesslin, A.R. Some properties of perfluorocarboxylic acids. Industr. Eng. Chem. 1986, 46, 2332-2334. [CrossRef]

2. Shinoda, K.; Hato, M.; Hayashi, T. Physicochemical properties of aqueous solutions of fluorinated surfactants. J. Phys. Chem. 1972, 76, 909-914. [CrossRef]

3. Lau, C.; Anitole, K.; Hodes, C.; Lai, D.; Pfahles-Hutchens, A.; Seed, J. Perfluoroalkyl Acids: A Review of Monitoring and Toxicological Findings. Toxicol. Sci. 2007, 99, 366-394. [CrossRef] [PubMed]

4. Xiao, F. Emerging poly-and perfluoroalkyl substances in the aquatic environment: A review of current literature. Water Res. 2017, 124, 482-495. [CrossRef] [PubMed]

5. Kissa, E. Fluorinated Surfactants and Repellants, 2nd ed.; Marcel Dekker Inc.: New York, NY, USA, 2001; ISBN 0-8247-0472-X.

6. Interstate Technology Regulatory Council. Naming Conventions and Physical and Chemical Properties. Updated 16-3-18. Interstate Technology Regulatory Council Fact Sheet. 2018. Available online: https://pfas-1. itrcweb.org/wp-content/uploads/2018/03/pfas_fact_sheet_naming_conventions_3_16_18.pdf (accessed on 3 July 2019).

7. Prevedouros, K.; Cousins, I.T.; Buck, R.C.; Korzeniowski, S.H. Sources, Fate and Transport of Perfluorocarboxylates. Environ. Sci. Technol. 2006, 40, 32-44. [CrossRef] [PubMed]

8. Vedagiri, U.K.; Anderson, R.H.; Loso, H.M.; Schwach, C.M. Ambient levels of PFOS and PFOA in multiple environmental media. Remediat. J. 2018, 28, 9-51. [CrossRef]

9. Interstate Technology Regulator Council. Environmental Fate and Transport. Interstate Technology Regulatory Council Fact Sheet. 2018. Available online: https://pfas-1.itrcweb.org/wp-content/uploads/2018/ 03/pfas_fact_sheet_fate_and_transport_3_16_18.pdf (accessed on 3 July 2019).

10. Giesy, J.P.; Naile, J.E.; Khim, J.S.; Jones, P.D.; Newsted, J.L. Aquatic Toxicology of Perfluorinated Chemicals. Rev. Environ. Contam. Toxicol. 2010, 202, 1-52. [PubMed]

11. Giesy, J.P.; Kannan, K. Global Distribution of Perfluorooctane Sulfonate in Wildlife. Environ. Sci. Technol. 2001, 35, 1339-1342. [CrossRef] 
12. Gayland, S. Per and Polyfluorinated Alkyl Substances (PFAS) in the Marine Environment-Preliminary Ecological Findings, South Australian Environment Protection Authority, Adelaide, Australia. 2017. Available online: https://www.epa.sa.gov.au/files/12580_report_pfas_marine.pdf (accessed on 3 July 2019).

13. McCarthy, C.; Kappleman, W.; DiGuiseppi, W. Ecological Considerations of Per- and Polyfluoroalkyl Substances (PFAS). Curr. Pollut. Rep. 2017, 3, 289-301. [CrossRef]

14. Kannan, K.; Corsolini, S.; Falandysz, J.; Fillmann, G.; Kumar, K.S.; Loganathan, B.G.; Mohd, M.A.; Olivero, J.; Van Wouwe, N.; Yang, J.H.; et al. Perfluorooctanesulfonate and Related Fluorochemicals in Human Blood from Several Countries. Environ. Sci. Technol. 2004, 38, 4489-4495. [CrossRef]

15. Weiss, P.T.; Gulliver, J.S.; Erickson, A.J. Cost and Pollutant Removal of Storm-Water Treatment Practices. J. Water Resour. Plan. Manag. 2007, 133, 218-229. [CrossRef]

16. United Nations Environment Program. Stocknolm Convention on Persistent Organic Pollutants (POPs): The 16 New POPs. United Nations Environment, Stockholm. 2017. Available online: http://www.pops.int/ TheConvention/ThePOPs/TheNewPOPs/tabid/2511/Default.aspx (accessed on 28 November 2018).

17. United States Environmental Protection Agency. Lifetime Health Advisories and Health Effects Support Documents for Perfluorooctanoic Acid and Perfluorooctane Sulfonate; United States Environmental Protection Agency: Washington, DC, USA, 2016. Available online: https://www.epa.gov/ground-water-and-drinkingwater/drinking-water-health-advisories-pfoa-and-pfos (accessed on 20 August 2019).

18. Canadian Government. Canadian Environmental Protection Act, 1999; Federal Environmental Quality Guidelines, Perfluorooctane Sulfonate (PFOS), 2017. Available online: https://www.canada.ca/en/environment-climatechange/services/evaluating-existing-substances/federal-environmental-quality-guidelinesperfluorooctanesulfonate.html (accessed on 20 August 2019).

19. Heads of Environmental Protection Agencies, PFAS. National Environmental Management Plan, January 2018 . Heads of EPA Australian and New Zealand (HEPA), 2018. Available online: http://www.environment. gov.au/protection/chemicals-management/pfas (accessed on 3 July 2019).

20. Hu, X.C.; Andrews, D.Q.; Lindstrom, A.B.; Bruton, T.A.; Schaider, L.A.; Grandjean, P.; Lohmann, R.; Carignan, C.C.; Blum, A.; Balan, S.A.; et al. Detection of Poly-and Perfluoroalkyl Substances (PFASs) in U.S. Drinking Water Linked to Industrial Sites, Military Fire Training Areas, and Wastewater Treatment Plants. Environ. Sci. Technol. Lett. 2016, 3, 344-350. [CrossRef] [PubMed]

21. Winkens, K.; Vestergren, R.; Berger, U.; Cousins, I.T. Early life exposure to per-and polyfluoroalkyl substances (PFASs): A critical review. Emerg. Contam. 2017, 3, 55-68. [CrossRef]

22. Valsecchi, S.; Conti, D.; Crebelli, R.; Polesello, S.; Rusconi, M.; Mazzoni, M.; Preziosi, E.; Carere, M.; Lucentini, L.; Ferretti, E.; et al. Deriving environmental quality standards for perfluorooctanoic acid (PFOA) and related short chain perfluorinated alkyl acids. J. Hazard. Mater. 2017, 323, 84-98. [CrossRef] [PubMed]

23. New Zealand Ministry for the Environment. Impact of Per and Poly Fluoroalkyl Substances on Ecosystems, New Zealand Ministry for the Environment, (NZMftE). 2018; 130p. Available online: http://www.mfe.govt. nz/sites/default/files/media/Land/final-impact-of-pfas-on-ecosystems_0.pdf (accessed on 3 July 2019).

24. Interstate Technology Regulatory Council. Remediation Technologies and Methods for Per-and Polyfluoroalkyl Substances (PFAS. Updated 16-3-18. Interstate Technology Regulatory Council Fact Sheet. Available online: https://pfas-1.itrcweb.org/wp-content/uploads/2018/03/pfas_fact_sheet_remediation_3_15_18.pdf (accessed on 3 July 2019).

25. Ahrens, L.; Yeung, L.W.; Taniyasu, S.; Lam, P.K.; Yamashita, N. Partitioning of perfluorooctanoate (PFOA), perfluorooctane sulfonate (PFOS) and perfluorooctane sulfonamide (PFOSA) between water and sediment. Chemosphere 2011, 85, 731-737. [CrossRef] [PubMed]

26. Yu, J.; Hu, J.; Tanaka, S.; Fujii, S. Perfluorooctane sulfonate (PFOS) and perfluorooctanoic acid (PFOA) in sewage treatment plants. Water Res. 2009, 43, 2399-2408. [CrossRef] [PubMed]

27. Dillon, P. Future management of aquifer recharge. Hydrogeol. J. 2005, 13, 313-316. [CrossRef]

28. Page, D.; Bekele, E.; Vanderzalm, J.; Sidhu, J. Managed Aquifer Recharge (MAR) in Sustainable Urban Water Management. Water 2018, 10, 239. [CrossRef]

29. Page, D.; Vanderzalm, J.; Dillon, P.; Gonzalez, D.; Barry, K. Stormwater Quality Review to Evaluate Treatment for Drinking Water Supply via Managed Aquifer Recharge. Water Air Soil Pollut. 2016, 227, 1-16. [CrossRef]

30. Simcik, M.F.; Dorweiler, K.J. Ratio of Perfluorochemical Concentrations as a Tracer of Atmospheric Deposition to Surface Waters. Environ. Sci. Technol. 2005, 39, 8678-8683. [CrossRef] 
31. Zushi, Y.; Takeda, T.; Masunaga, S. Existence of nonpoint source of perfluorinated compounds and their loads in the Tsurumi River basin, Japan. Chemosphere 2008, 71, 1566-1573. [CrossRef]

32. Murakami, M.; Shinohara, H.; Takada, H. Evaluation of wastewater and street runoff as sources of perfluorinated surfactants (PFSs). Chemosphere 2009, 74, 487-493. [CrossRef]

33. Murakami, M.; Kuroda, K.; Sato, N.; Fukushi, T.; Takizawa, S.; Takada, H. Groundwater pollution by perfluorinated surfactants in Tokyo. Environ. Sci. Technol. 2009, 43, 3480-3486. [CrossRef]

34. Xiao, F.; Simcik, M.F.; Gulliver, J.S. Perfluoroalkyl acids in urban stormwater runoff: Influence of land use. Water Res. 2012, 46, 6601-6608. [CrossRef]

35. Houtz, E.F.; Sedlak, D.L. Oxidative conversion as a means of detecting precursors to perfluoroalkyl acids in urban runoff. Environ. Sci. Technol 2012, 46, 9342-9349. [CrossRef] [PubMed]

36. Kim, S.-K.; Kannan, K. Perfluorinated acids in air, rain, snow, surface runoff, and lakes: Relative importance of pathways to contamination of urban lakes. Environ. Sci. Technol. 2007, 41, 8328-8334. [CrossRef] [PubMed]

37. Loos, R.; Carvalho, R.; António, D.C.; Comero, S.; Locoro, G.; Tavazzi, S. EU-wide monitoring survey on emerging polar organic contaminants inwastewater treatment plant effluents. Water Res. 2013, 47, 6475-6487. [CrossRef]

38. Schultz, M.M.; Higgins, C.P.; Huset, C.A.; Luthy, R.G.; Barofsky, D.F.; Field, J.A. Fluorochemical Mass Flows in a Municipal Wastewater Treatment Facility. Environ. Sci. Technol. 2006, 40, 7350-7357. [CrossRef] [PubMed]

39. Becker, A.M.; Gerstmann, S.; Frank, H. Perfluorooctane surfactants in waste waters, the major source of river pollution. Chemosphere 2008, 72, 115-121. [CrossRef]

40. Zareitalabad, P.; Siemens, J.; Hamer, M.; Amelung, W. Perfluorooctanoic acid (PFOA) and perfluorooctanesulfonic acid (PFOS) in surface waters, sediments, soils and wastewater-A review on concentrations and distribution coefficients. Chemosphere 2013, 91, 725-732. [CrossRef]

41. Radcliffe, J.C. Future directions for water recycling in Australia. Desalination 2006, 187, 77-87. [CrossRef]

42. Sinclair, E.; Kannan, K. Mass Loading and Fate of Perfluoroalkyl Surfactants in Wastewater Treatment Plants. Environ. Sci. Technol. 2006, 40, 1408-1414. [CrossRef] [PubMed]

43. Loganathan, B.G.; Sajwan, K.S.; Sinclair, E.; Kumar, K.S.; Kannan, K. Perfluoroalkyl sulfonates and perfluorocarboxylates in two wastewater treatment facilities in Kentucky and Georgia. Water Res. 2007, 41, 4611-4620. [CrossRef] [PubMed]

44. Thompson, J.; Eaglesham, G.; Reungoat, J.; Poussade, Y.; Bartkow, M.; Lawrence, M.; Mueller, J.F. Removal of PFOS, PFOA and other perfluoroalkyl acids at water reclamation plants in South East Queensland Australia. Chemosphere 2011, 82, 9-17. [CrossRef] [PubMed]

45. Eriksson, U.; Haglund, P.; Kärrman, A. Contribution of precursor compounds to the release of per- and polyfluoroalkyl substances (PFASs) from waste water treatment plants (WWTPs). J. Environ. Sci. 2017, 61, 80-90. [CrossRef] [PubMed]

46. Li, X.; Yeung, L.W.Y.; Xu, M.; Taniyasu, S.; Lam, P.K.; Yamashita, N.; Dai, J. Perfluorooctane sulfonate (PFOS) and other fluorochemicals in fish blood collected near the outfall of wastewater treatment plant (WWTP) in Beijing. Environ. Pollut. 2008, 156, 1298-1303. [CrossRef] [PubMed]

47. Espana, V.A.A.; Mallavarapu, M.; Naidu, R. Treatment technologies for aqueous perfluorooctanesulfonate (PFOS) and perfluorooctanoate (PFOA): A critical review with an emphasis on field testing. Environ. Technol. Innov. 2015, 4, 168-181. [CrossRef]

48. Kucharzyk, K.H.; Darlington, R.; Benotti, M.; Deeb, R.; Hawley, E. Novel treatment technologies for PFAS compounds: A critical review. J. Environ. Manag. 2017, 204, 757-764. [CrossRef] [PubMed]

49. Ross, I.; McDonough, J.; Miles, J.; Storch, P.; Kochunarayanan, P.T.; Kalve, E.; Hurst, J.; Dasgupta, S.S.; Burdick, J. A review of emerging technologies for remediation of PFASs. Remediat. J. 2018, 28, 101-126. [CrossRef]

50. Vecitis, C.D.; Park, H.; Cheng, J.; Mader, B.T.; Hoffmann, M.R. Treatment technologies for aqueous perfluorooctanesulfonate (PFOS) and perfluorooctanoate (PFOA). Front. Environ. Sci. Eng. China 2009, 3, 129-151. [CrossRef]

51. Ochoa-Herrera, V.; Luna-Velasco, A.; Field, J.A.; Sierra-Alvarez, R. Microbial toxicity and biodegradability of perfluorooctane sulfonate (PFOS) and shorter chain perfluoroalkyl and polyfluoroalkyl substances (PFASs). Environ. Sci. Process. Impacts 2016, 18, 1236-1246. [CrossRef] [PubMed] 
52. Rayne, S.; Forest, K. Perfluoroalkyl sulfonic and carboxylic acids: A critical review of physicochemical properties, levels and patterns in waters and wastewaters, and treatment methods. J. Environ. Sci. Health Part A 2009, 44, 1145-1199. [CrossRef] [PubMed]

53. Boonya-Atichart, A.; Boontanon, S.K.; Boontanon, N. Removal of perfluorooctanoic acid (PFOA) in groundwater by nanofiltration membrane. Water Sci. Technol. 2016, 74, 2627-2633. [CrossRef] [PubMed]

54. Tang, C.Y.; Fu, Q.S.; Robertson, A.P.; Criddle, C.S.; Leckie, J.O. Use of reverse osmosis membranes to remove perfluorooctane sulfonate (PFOS) from semiconductor wastewater. Environ. Sci. Technol. 2006, 40, 7343-7349. [CrossRef] [PubMed]

55. Tang, C.Y.; Fu, Q.S.; Criddle, C.S.; Leckie, J.O. Effect of flux (transmembrane pressure) and membrane properties on fouling and rejection of reverse osmosis and nanofiltration membranes treating perfluorooctane sulfonate containing wastewater. Environ. Sci. Technol. 2007, 41, 2008-2014. [CrossRef] [PubMed]

56. Gorenflo, A.; Velazquez-Padron, D.; Frimmel, F.H. Nano-filtration of a German groundwater of high hardness and NOM content: Performance and costs. Desalination 2003, 151, 253-265. [CrossRef]

57. Schaep, J.; Van Der Bruggen, B.; Uytterhoeven, S.; Croux, R.; Vandecasteele, C.; Wilms, D.; Van Houtte, E.; Vanlerberghe, F. Removal of hardness from groundwater by nanofiltration. Desalination 1998, 119, $295-301$. [CrossRef]

58. Tang, H.; Xiang, Q.; Lei, M.; Yan, J.; Zhu, L.; Zou, J. Efficient degradation of perfluorooctanoic acid by UV-Fenton process. Chem. Eng. J. 2012, 184, 156-162. [CrossRef]

59. Hori, H.; Yamamoto, A.; Hayakawa, E.; Taniyasu, S.; Yamashita, N.; Kutsuna, S.; Kiatagawa, H.; Arakawa, R. Efficient Decomposition of Environmentally Persistent Perfluorocarboxylic Acids by Use of Persulfate as a Photochemical Oxidant. Environ. Sci. Technol. 2005, 39, 2383-2388. [CrossRef]

60. Hori, H.; Nagaoka, Y.; Murayama, M.; Kutsuna, S. Efficient decomposition of perfluorocarboxylic acids and alternative fluorochemical surfactants in hot water. Environ. Sci. Technol. 2008, 42, 7438-7443. [CrossRef]

61. Kingshott, L.M. Remedial Approaches for Perfluorooctane Sulfonate. Master's Thesis, Imperial College London, London, UK, 2008.

62. Song, Z.; Tang, H.; Wang, N.; Zhu, L. Reductive defluorination of perfluorooctanoic acid by hydrated electrons in a sulfite-mediated UV photochemical system. J. Hazard. Mater. 2013, 262, 332-338. [CrossRef] [PubMed]

63. Hori, H.; Nagaoka, Y.; Yamamoto, A.; Sano, T.; Yamashita, N.; Taniyasu, S. Efficient decomposition of environmentally persistent perfluorooctanesulfonate and related fluorochemicals using zero valent iron in subcritical water. Environ. Sci. Technol. 2006, 40, 1049-1054. [CrossRef]

64. Vecitis, C.D.; Wang, Y.; Cheng, J.; Park, H.; Mader, B.T.; Hoffmann, M.R. Sonochemical Degradation of Perfluorooctanesulfonate in Aqueous Film-Forming Foams. Environ. Sci. Technol. 2010, 44, 432-438. [CrossRef] [PubMed]

65. Collings, A.; Gwan, P.; Sosa-Pintos, A. Large scale environmental applications of high power ultrasound. Ultrason. Sonochem. 2010, 17, 1049-1053. [CrossRef]

66. Cheng, J.; Vecitis, C.D.; Park, H.; Mader, B.T.; Hoffmann, M.R. Sonochemical Degradation of Perfluorooctane Sulfonate (PFOS) and Perfluorooctanoate (PFOA) in Landfill Groundwater: Environmental Matrix Effects. Environ. Sci. Technol. 2008, 42, 8057-8063. [CrossRef] [PubMed]

67. Fernandez, N.A.; Rodriguez-Freire, L.; Keswani, M.; Sierra-Alvarez, R. Effect of chemical structure on the sonochemical degradation of perfluoroalkyl and polyfluoroalkyl substances (PFASs). Environ. Sci. Water Res. Technol. 2016, 2, 975-983. [CrossRef]

68. Simonite, T. Sound Blaster Cleans Contaminated Soil. 2006. Available online: https://www.newscientist.com/ article/dn10008-sound-blaster-cleans-contaminated-soil/. (accessed on 3 July 2019).

69. Merino, N.; Qu, Y.; Deeb, R.A.; Hawley, E.L.; Hoffmann, M.R.; Mahendra, S. Degradation and Removal Methods for Perfluoroalkyl and Polyfluoroalkyl Substances in Water. Environ. Eng. Sci. 2016, 33, 615-649. [CrossRef]

70. Conder, J.M.; Hoke, R.A.; Wolf, W.D.; Russell, M.H.; Buck, R.C. Are PFCAs bioaccumulative? A critical review and comparison with regulatory criteria and persistent lipophilic compounds. Environ. Sci. Technol. 2008, 42, 995-1003. [CrossRef]

71. Australia New Zealand Guidelines. Australian and New Zealand Guidelines for Fresh and Marine Water Quality, Australian and New Zealand Governments. 2018. Available online: http://www.waterquality.gov. au/guidelines (accessed on 3 July 2019). 
72. Australian Government Department of Health. Health Based Guidance Values for PFAS for Use in Site Investigations in Australia. 2017. Available online: http://www.health.gov.au/internet/main/publishing.nsf/ Content/2200FE086D480353CA2580C900817CDC/\$File/fs-Health-Based-Guidance-Values.pdf (accessed on 3 July 2019).

73. National Environmental Management Plan. 2018; (PFAS NEMP). Available online: http://www.environment. gov.au/protection/chemicals-management/pfas (accessed on 21 November 2018).

74. Page, D.; Miotliński, K.; Gonzalez, D.; Barry, K.; Dillon, P.; Gallen, C. Environmental monitoring of selected pesticides and organic chemicals in urban stormwater recycling systems using passive sampling techniques. J. Contam. Hydrol. 2014, 158, 65-77. [CrossRef]

75. Greskowiak, J.; Hamann, E.; Burke, V.; Massmann, G. The uncertainty of biodegradation rate constants of emerging organic compounds in soil and groundwater-A compilation of literature values for 82 substances. Water Res. 2017, 126, 122-133. [CrossRef]

76. Tiehm, A.; Schmidt, N.; Page, D. Biodegradation of pharmaceuticals and endocrine disruptors with oxygen, nitrate, manganese (IV), iron (III) and sulfate as electron acceptors. J. Contam. Hydrol. 2017, 203, 62-69.

77. Shareef, A.; Page, D.; Vanderzalm, J.; Williams, M.; Gupta, V.; Dillon, P.; Kookana, R. Biodegradation of two herbicides simazine and diuron during managed aquifer recharge of stormwater. Clean Soil Air Water 2013, 42, 745-752. [CrossRef]

78. Ying, G.G.; Toze, S.; Hanna, J.; Yu, X.Y.; Dillon, P.J.; Kookana, R.S. Decay of endocrine-disrupting chemicals in aerobic and anoxic groundwater. Water Res. 2008, 42, 1133-1141. [CrossRef] [PubMed]

79. Alotaibi, M.; Patterson, B.; McKinley, A.; Reeder, A.; Furness, A.; Donn, M.; McKinley, A. Fate of benzotriazole and 5-methylbenzotriazole in recycled water recharged into an anaerobic aquifer: Column studies. Water Res. 2015, 70, 184-195. [CrossRef] [PubMed]

80. Patterson, B.; Pitoi, M.; Furness, A.; Bastow, T.; McKinley, A.; McKinley, A. Fate of N-Nitrosodimethylamine in recycled water after recharge into anaerobic aquifer. Water Res. 2012, 46, 1260-1272. [CrossRef] [PubMed]

81. Liou, J.C.; Szostek, B.; DeRito, C.; Madsen, E. Investigating the biodegradability of perfluorooctanoic acid. Chemosphere 2010, 80, 176-183. [CrossRef]

82. Vaalgamaa, S.; Vähätalo, A.V.; Perkola, N.; Huhtala, S. Photochemical reactivity of perfluorooctanoic acid (PFOA) in conditions representing surface water. Sci. Total Environ. 2011, 409, 3043-3048. [CrossRef]

83. Post, G.B.; Cohn, P.D.; Cooper, K.R. Perfluorooctanoic acid (PFOA), an emerging drinking water contaminant: A critical review of recent literature. Environ. Res. 2012, 116, 93-117. [CrossRef]

84. AECOM. Stage 2C Environmental Investigation-Groundwater and Surface water monitoring: July 2017 to May 2018. Army Aviation Centre Oakey, Oakey QLD. Report Prepared by AECOM Australia Pty Ltd. 2018. Available online: www.defence.gov.au/Environment/PFAS/Docs/Oakey/Reports/201810OakeyGME.pdf (accessed on 3 July 2019).

85. AECOM. Environmental Site Assessment, December 2017. RAAF Base Williamstown Stage 2B Environmental Investigation. Report Prepared by AECOM Australia Pty Ltd.; 2017. Available online: www.defence.gov.au/ Environment/PFAS/./Williamtown/./20171205ESAFindings.pdf (accessed on 3 July 2019).

86. Li, Y.; Oliver, D.P.; Kookana, R.S. A critical analysis of published data to discern the role of soil and sediment properties in determining sorption of per and polyfluoroalkyl substances (PFASs). Sci. Total. Environ. 2018, 110-120. [CrossRef]

87. Ferrey, M.L.; Wilson, J.T.; Adair, C.; Su, C.; Fine, D.D.; Liu, X.; Washington, J.W. Behavior and Fate of PFOA and PFOS in Sandy Aquifer Sediment. Ground Water Monit. Remediat. 2012, 32, 63-71. [CrossRef]

88. Higgins, C.P.; Luthy, R.G. Sorption of Perfluorinated Surfactants on Sediments. Environ. Sci. Technol. 2006, 40, 7251-7256. [CrossRef] [PubMed]

89. Hellsing, M.J.; Josefsson, S.; Hughes, A.V.; Ahrens, L. Sorption of perfluroalkyl substances to two types of minerals. Chemosphere 2016, 159, 385-391. [CrossRef] [PubMed]

90. Vanderzalm, J.; Salle, C.L.G.L.; Dillon, P. Fate of organic matter during aquifer storage and recovery (ASR) of reclaimed water in a carbonate aquifer. Appl. Geochem. 2006, 21, 1204-1215. [CrossRef]

91. Vanderzalm, J.; Dillon, P.; Barry, K.; Miotlinski, K.; Kirby, J.; Salle, C.L.G.L. Arsenic mobility and impact on recovered water quality during aquifer storage and recovery using reclaimed water in a carbonate aquifer. Appl. Geochem. 2011, 26, 1946-1955. [CrossRef] 
92. Vanderzalm, J.L.; Page, D.W.; Barry, K.E.; Dillon, P.J. A comparison of the geochemical response to different managed aquifer recharge operations for injection of urban storm water in a carbonate aquifer. Appl. Geochem. 2010, 25, 1350-1360. [CrossRef]

93. Miotliński, K.; Dillon, P.J.; Pavelic, P.; Cook, P.G.; Page, D.W.; Levett, K. Recovery of injected freshwater to differentiate fracture flow in a low-permeability brackish aquifer. J. Hydrol. 2011, 409, 273-282. [CrossRef]

94. Herczeg, A.L.; Rattray, K.J.; Dillon, P.J.; Pavelic, P.; Barry, K.E. Geochemical Processes During Five Years of Aquifer Storage Recovery. Ground Water 2004, 42, 438-445. [CrossRef]

95. Barry, K.; Vanderzalm, J.; Miotlinski, K.; Dillon, P. Assessing the impact of recycled water quality and clogging on infiltration rates at a pioneering soil aquifer treatment (SAT) site in Alice Springs, Northern Territory (NT), Australia. Water 2017, 9, 179. [CrossRef]

96. Gates, W.; Janik, L.; Pavelic, P.; Dillon, P.; Barry, K. Characterisation of the Physical and Geochemical Properties and Infrared Spectra of Five Soil Cores at the AZRI Site near Alice Springs, Northern Territory. CSIRO: Canberra, Australia. Available online: http://www.clw.csiro.au/publications/waterforahealthycountry/2009/ wfhc-characterisation-AZRI-site.pdf (accessed on 19 August 2019).

97. Prommer, H.; Descourvieres, C.D.; Handyside, M.; Johnston, K.; Harris, B.; Li, Q.; Fang, H.; Costello, P.; Seibert, S.; Martin, M. Final Report-Aquifer storage and Recovery of Potable Water in the Leederville Aquifer. Water for a Healthy Country National Research Flagship; CSIRO: Perth, Australia, 2013; Available online: https://publications.csiro.au/rpr/pub?pid=csiro:EP136027 (accessed on 3 July 2019).

98. Page, D.W.; Miotlinski, K.; Dillon, P.; Taylor, R.; Wakelin, S.; Levett, K.; Barry, K.; Pavelic, P. Stormwater pre-treatment options for sustaining aquifer storage and recovery in low permeability fractured rock aquifer. J. Environ. Manag. 2011, 92, 2410-2418. [CrossRef]

99. Bekele, E.; Toze, S.; Patterson, B.; Higginson, S. Managed aquifer recharge of treated wastewater: Water quality changes resulting from infiltration through the vadose zone. Water Res. 2011, 45, 5764-5772. [CrossRef]

100. Bekele, E.; Toze, S.; Patterson, B.; Fegg, W.; Shackleton, M.; Higginson, S. Evaluating two infiltration gallery designs for managed aquifer recharge using secondary treated wastewater. J. Environ. Manag. 2013, 117, 115-120. [CrossRef] [PubMed]

101. Bekele, E.; Patterson, B.; Toze, S.; Furness, A.; Higginson, S.; Shackleton, M. Aquifer residence times for recycled water estimated using chemical tracers and the propagation of temperature signals at a managed aquifer recharge site in Australia. Hydrogeol. J. 2014, 22, 1383-1401. [CrossRef]

102. Liu, J.; Avendaño, S.M. Microbial degradation of polyfluoroalkyl chemicals in the environment: A review. Environ. Int. 2013, 61, 98-114. [CrossRef] [PubMed]

103. Regnery, J.; Gerba, C.P.; Dickenson, E.R.V.; Drewes, J.E. The importance of key attenuation factors for microbial and chemical contaminants during managed aquifer recharge: A review. Crit. Rev. Environ. Sci. Technol. 2017, 47, 1409-1452. [CrossRef]

104. Parsons, J.R.; Sáez, M.; Dolfing, J.; De Voogt, P. Biodegradation of perfluorinated compounds. Rev. Environ. Contam. Toxicol. 2008, 196, 53-71. [PubMed]

105. Patterson, B.M.; Bekele, E.B. A novel technique for estimating wetting front migration rates through the vadose zone based on changes in groundwater velocity. J. Hydrol. 2011, 409, 538-544. [CrossRef]

106. Kodešová, R.; Grabic, R.; Kočárek, M.; Klement, A.; Golovko, O.; Fér, M.; Nikodem, A.; Jakšík, O. Pharmaceuticals' sorptions relative to properties of thirteen different soils. Sci. Total Environ. 2015, 511, 435-443. [CrossRef] [PubMed]

107. Christiano, E.; Hu, Y.J.; Siegried, M.; Nitsche, H. A comparison of point of zero charge measurement methodology. Clays Clay Miner. 2011, 59, 107-115. [CrossRef]

108. Johnson, R.; Anschutz, A.; Smolen, J.; Simcik, M.; Lee Penn, R. The Adsorption of Perfluorooctane Sulfonate onto Sand, Clay, and Iron Oxide Surfaces. J. Chem. Eng. Data 2007, 52, 1165-1170. [CrossRef]

109. Somasundaran, P.; Agar, G. The zero point of charge of calcite. J. Colloid Interface Sci. 1967, 24, $433-440$. [CrossRef]

110. Natural Resource Ministerial Management Council; Environmental Protection Heritage Council; National Health Medical Research Council. Australian Guidelines for Water Recycling: Managing Health And Environmental Risks (Phase 2), Augmentation of Drinking Water Supplies. Natural Resource Ministerial Management Council; Environment Protection and Heritage Council; National Health and Medical Research Council: Canberra, Australia. Available online: https://www.nhmrc.gov.au/file/2686/download?token=3_ 6bfluL (accessed on 3 July 2019). 
111. Stahl, T.; Heyn, J.; Thiele, H.; Hüther, J.; Failing, K.; Georgii, S.; Brunn, H. Carryover of perfluorooctanoic acid (PFOA) and perfluorooctane sulfonate (PFOS) from soil to plants. Arch. Environ. Contam. Toxicol. 2009, 57, 289-298. [CrossRef] [PubMed]

112. Lechner, M.; Knapp, H. Carryover of perfluorooctanoic acid (PFOA) and perfluorooctane sulfonate (PFOS) from soil to plant and distribution to the different plant compartments studied in cultures of carrots (Daucus carota ssp. sativus), potatoes (Solanum tuberosum), and cucumbers (Cucumis sativus). J. Agric. Food Chem. 2011, 59, 11011-11018. [PubMed]

113. Scher, D.P.; Kelly, J.E.; Huset, C.A.; Barry, K.M.; Hoffbeck, R.W.; Yingling, V.L.; Messing, R.B. Occurrence of perfluoroalkyl substances (PFAS) in garden produce at homes with a history of PFAS-contaminated drinking water. Chemosphere 2018, 196, 548-555. [CrossRef] [PubMed]

114. National Ground Water Association. Groundwater and PFAS: State of Knowledge and Practice. National Groundwater Association Press. Available online: https://www.ngwa.org/publications-andnews/Newsroom/2018-press-releases/ngwa-releases-groundwater-and-pfas (accessed on 3 July 2019).

(C) 2019 by the authors. Licensee MDPI, Basel, Switzerland. This article is an open access article distributed under the terms and conditions of the Creative Commons Attribution (CC BY) license (http://creativecommons.org/licenses/by/4.0/). 